\title{
Hybrid
}

Revue des arts et médiations humaines

$7 \mid 2021$

Le réseau créatif des langu.ages

\section{Straight quotes, square brackets: Page-based poetics inflected with the syntax and grammar of code languages}

\section{J. R. Carpenter}

\section{OpenEdition}

Journals

Electronic version

URL: https://journals.openedition.org/hybrid/684

DOI: 10.4000/hybrid.684

ISSN: 2276-3538

Translation(s):

Guillemets et crochets : de l'influence de la syntaxe et de la grammaire des langages de code sur une poétique de la page - URL : https://journals.openedition.org/hybrid/691 [fr]

Publisher

Presses universitaires de Vincennes

\section{Electronic reference}

J. R. Carpenter, "Straight quotes, square brackets: Page-based poetics inflected with the syntax and grammar of code languages", Hybrid [Online], 7| 2021, Online since 08 April 2021, connection on 13 April 2022. URL: http://journals.openedition.org/hybrid/684 ; DOI: https://doi.org/10.4000/hybrid.684

This text was automatically generated on 13 April 2022.

Revue Hybrid 


\title{
Straight quotes, square brackets: Page-based poetics inflected with the syntax and grammar of code languages
}

\author{
J. R. Carpenter
}

\section{Introduction}

1 In English, the word "translation" is formed of two parts. The prefix trans- meaning across, beyond, or through, is applied to the word -lation, from the Latin, latio, meaning borne, as in carried or endured. I must confess from the outset that I am more interested in trans- than in -lation. Trans- as I will use it here refers to a process, a movement, an event; -lation is a commitment, a burden, work.

2 The prefix trans- may be used to span vast distances: transcontinental, transatlantic. Or, it may imply a state of change: transmit, transfer, transport. Or, somewhat more abstractly, it may imply a poetics of coming and going: transverse. From the Latin versus: literally, a turning, to turn. Every verse has a re-verse. In Greek verse, Strophe speaks from east to west across the stage. Antistrophe replies from west to east. Neither voice is in either place. Both are calling: across, beyond, through.

3 As a writer, and as a migrant, I live and work in in-between places and spaces: between English and French languages, between print and digital media; between poetry and academia. In English it seems, one is often caught between extremes: between a rock and a hard place, between the frying pan and the fire. So too in translation, a perception of dualism persists: between the pre-text and the post-text, the original and the copy. In French, "between" is a third space - l'entrespace. This article will occupy this third space as a dynamic site of intersection. It will be written in English, but it will think in part in French. 
4 This article builds upon a paper that was presented at "Multilingual Digital Authorship," a symposium hosted by Erika Fülöp at Lancaster University on 8 March 2018. That paper was later expanded into a public lecture which was presented at the Heine Haus Literaturhaus Düsseldorf, at the invitation of the Summer School Literaturübersetzen: Translation and the Digital World, on 28 June 2019. I bring these presentation contexts, which might otherwise be relegated to a footnote, into the body of the text here to highlight both the disciplinary frameworks which have informed this thinking, and the processes of translation already in operation in this text. This article traces the translation of texts between cultural and linguistic contexts, between academic and public-facing audiences, between print, digital, and performed forms.

In its current iteration as an online publication this article continues an on-going exploration of the movement of language across, beyond, and through in-between spaces. The idea of "between" is considered here as a third time/space/state, a texture, an event, a palpable unfolding fraught with cacophony, liminality, atemporality and asynchronous exchanges. In keeping with its transient subject, this article will alternate between lyrical and analytical modes.

\section{Mediation}

6 I have been using the internet as a medium for the creation and dissemination of experimental writing since 1993. I made my first web-based work in 1995. Since that time I have continued to explore the web's ever-expanding potential for multimodality, intertextuality, and the integration of image and text. I have also published five books. Much of my writing for the page comes through digital processes. Much of my digital writing never reaches the page. Where, then, does this writing reside? All digital writing operates in in-between spaces - between server-side and client side, between source code and output, between human and machine languages. As such, all digital writing is radically atemporal - operating simultaneously in the there of the server and the here of the local device, the if of the source code and the then of the screen.

7 A text displayed on a computer screen is always already a text in translation. The English poet John Hall notes: "A screen is something designed to substitute one appearance for another.... A screening is a showing and a hiding. Does it show to hide or hide to show?" Before we have time to ponder this question, digital writing leaps off the screen. It speeds as light through the elemental medium of air to alight on the wet surface of the eye of the reader. Instantly it is absorbed into the skull's dark interior.

8 When a digital text moves across global networks, through submarine cables, through air as wireless signals, through air as light, through the eye to the brain, and then out again, beyond the body as voice, re-entering the body as sound, what is borne across in the process? What trace of the digital endures on the page?

\section{Punctuation}

9 As its title suggests, this article is primarily concerned with questions of punctuation arising from the translation of poetic texts from digital into print contexts, with a particular attention to brackets and quotation marks. In Why do We Quote? The Culture 
and History of Quotation, Ruth Finnnegan observes: “[...] it is easy to take quote marks for granted without being particularly aware of them." "The conventions we use today "have undergone many changes over the centuries." ${ }^{3}$ Punctuation conventions vary greatly within and between English and French. They are more exacting within programming languages. A single missing or misplaced comma, bracket, or quotation mark will cause a program not to run. None of the punctuation necessary to the smooth running of a web page ought to be visible on the screen. Mistakes do happen>.

Unconventional use of punctuation can also be used to poetic effect. Adam O'Fallon Price argues: "Punctuation, largely invisible and insignificant for normal people, as it should be, is a highly personal matter for writers. Periods, commas, colons, semicolons: in their use or non-use and in their order and placement, can represent elaboration, conjecture, doubt, finality." ${ }^{4}$ What happens when a poet for the printed page is also an author of web pages? What happens when punctuation conventions from the source code rise to the surface of the screen? How might the syntax and grammar of code languages begin to inflect screen and page-based poetics?

\section{Entre Ville}

In 2006 I was commissioned to create a new web-based work for the fiftieth anniversary of the Conseil des Arts de Montréal. I write the title of the resulting work, Entre Ville (2006), in italics here, as it is the title of a stand-alone work akin to a book. If it were a single poem in a print collection in English the title would appear in single or double quotation marks, depending on the publication style guide: "Entre Ville" or "Entre Ville." The title is comprised of two French words: entre, meaning between; and ville, meaning city. This is a pun on the phrase centre-ville, meaning the centre of town in Canadian English, or downtown in vernacular. The locus of the work is not the centre of the city but rather the back alleyways, or ruelles, which run between the streets of the Mile End neighbourhood of Montréal. Entre Ville is, then, an in-between city, a city between us, a city entre nous.

In the web-based work, the title appears entre guillemets, between the style of quotation marks used in French: «Entre Ville ». Or, so it would seem. On closer inspection, the guillemets are not represented by their Unicode characters "». They are composed instead of greater-than and less-than symbols used as angle brackets $\ll>$, hinting at the grammar and syntax of another language lurking beneath the screen. If we view the source code of this page, we see that the title « Entre Ville $>$ is not composed of textual characters at all. It's an image file surrounded by double quotation marks and further enclosed in angle brackets:

$<$ img src="images/title_entreville_main.gif" width=580 height $=33$ border $=0$ alt="<<ENTRE VILLE>>"> 
Fig. 1

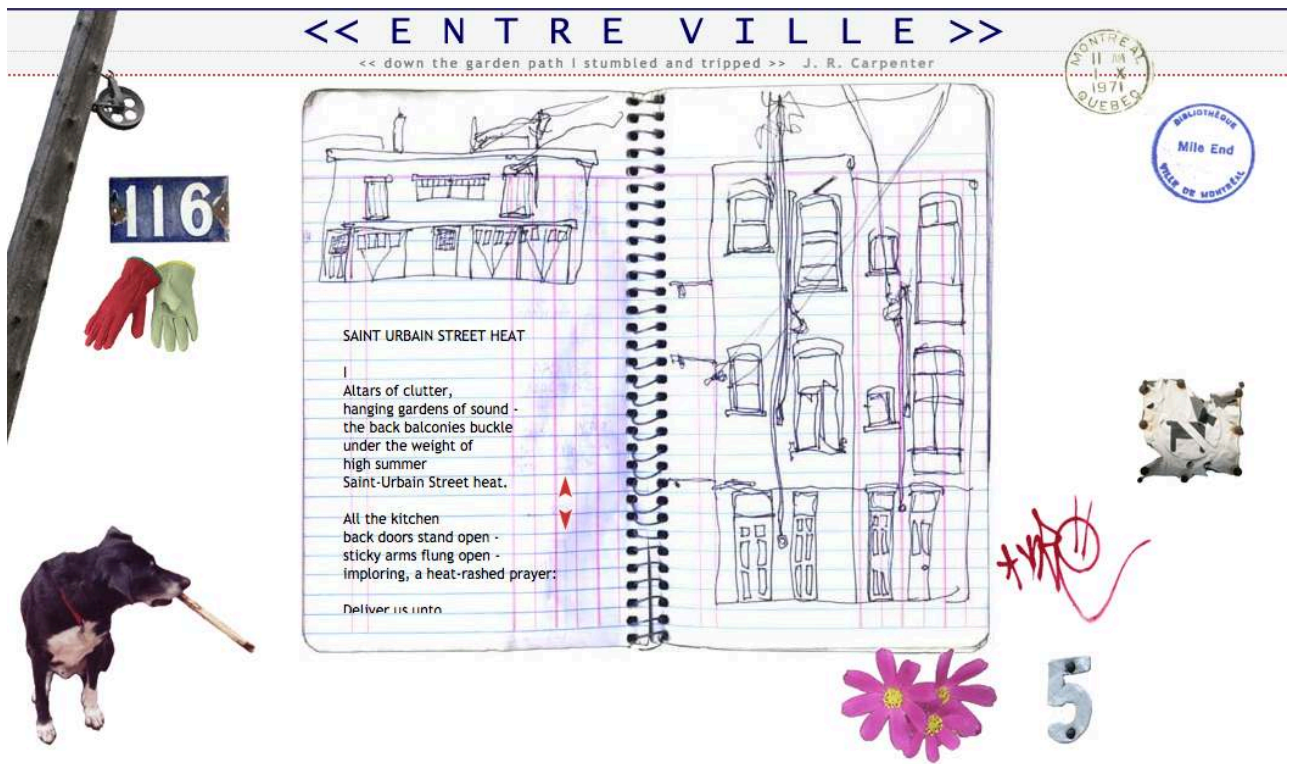

J. R. Carpenter, Entre Ville, 2006. [Online] http://luckysoap.com/entreville [accessed 13 April 2021]. tographic images, short videos, line drawings, spray-painted graffiti, a postage stamp, and rubbers stamps from library books. Jay David Bolter and Richard Grusin term the representation of one medium in another "remediation" and argue that "remediation is a defining characteristic of the new digital media." I query the directionality implied by this term. It seems to suggest that we are moving inexorably from print to digital. In this article I wish to demonstrate that these exchanges are rather more asynchronous. For example, my first novel, Words the Dog Knows (2008), remediated the text, setting, characters, and line drawings from my digital poem, Entre Ville, into a print novel. I then used the print novel as a script for the live performance of the web-based work. All three of these iterations - print, digital, and live performance - remediate a poem which was initially written on US Letter sized paper with a fountain pen. Trans- seems a more specific prefix than re- as it evokes the inbetween parts of this process, and -inter would also effectively encompass multi-lingual multi-media ecology referred to by this body of work. 


\section{GENERATION[S]}

16 generated stories presented alongside the program's source code which generates them. On pages which show stories, punctuation is represented according to print convention. On pages which show source code, the programming languages' conventions of punctuation are retained. In the digital realm, these texts are variable; they keep changing. In the print book as well as on screen, each output is but one possible translation of its source code, a transcription of the performance of JavaScript by a web browser. The print book reveals this digital process by interrupting it, by slowing it down.

GENERATION[S] also includes meta commentary on the composition of these hybrid print-digital texts. Some of this meta-commentary comes in the form of screenshots of emails and Facebook comment threads, further confusing the boundaries between print and digital. Contrary to Derrida's assertion that "the book is both the apparatus and the expiration date that makes us have to cut off the computer process," here the print book becomes a snapshot of an on-going digital literary process which would otherwise already be disappearing as soon as it is written. In This Little Art, Kate Briggs, the translator of Roland Barthes' late lectures, writes: "This is what the actual setting down of writing as distinct from the fantasy of writing is: a kind of catch of halt or temporary immobilization in the run of culture." ${ }^{8}$ The print book GENERATION[S] also serves as a reading machine, a point of entry into a digital compositional process, a tool for thinking about translating between print and digital texts.

\section{The Gathering Cloud}

My third book, The Gathering Cloud (2017), is a transmediation of an earlier web-based work by the same name (2016). There is also a small print zine iteration of this work. Chronology has no bearing here. Neither the book nor the zine nor the digital work is the original; all three are -lation, traces, borne or carried across as the ideas behind the work and the questions the work poses move through a continuum of forms. Perhaps it is useful here to move away from thinking about a singular art work towards a body of work. 
Fig. 2

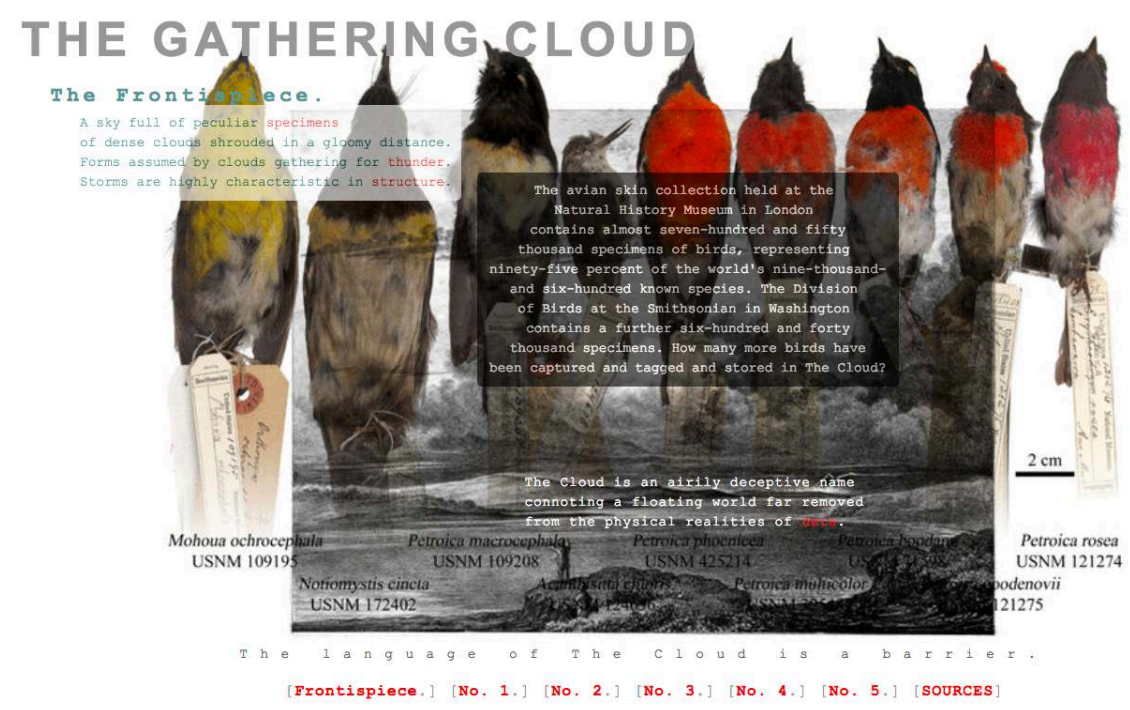

J. R. Carpenter, The Gathering Cloud, 2016. [Online] http://luckysoap.com/thegatheringcloud [accessed 13 April 2021].

19 As body of work, The Gathering Cloud is concerned with questions of transmutation. Whereas translation from one form to another implies an equivalency between forms, transmutation implies a sudden and/or radical change in form. This body of work springs from a deceptively simple question: Why do we call the digital cloud The Cloud? To answer this question, more than one medium was required. The print book charts the transmutation of human conceptions of the cloud through 2442 years of thought, from Aristophanes and Aristotle through to Amazon and Google. The digital poem focuses on addressing to the environmental impact of so-called cloud storage through the oblique strategy of calling attention to the materiality of clouds in the sky. Both are commonly thought to be ephemeral; both, decidedly, are not.

Both the print book and the digital poem are written in a loose hendecasyllabic verse, which is to say, in lines of eleven syllables. Most of these lines are found texts, borrowed from the work of other authors' writing on clouds and The cloud. None of these found texts have been identified as such by quotation marks. None of the authors have been named within the body of the work, though a list of sources is offered in both the digital and print iterations. McKenzie Wark argues: "Détournement is the opposite of quotation. Like détournement, quotation brings the past into the present, but it does so entirely within a regime of the proper use of proper names." ${ }^{9}$ For Gilles Deleuze and Félix Guattari "[t]he proper name is the instantaneous apprehension of a multiplicity." 10 As such, "[t] here are no individual statements. [...] Every statement is the product of a machinic assemblage." 11 Called as statements into a digital text process, these hendecasyllabic fragments are reconstituted in a present which is also a break from the present, in a new regime of enunciation, one in which authorship is distributed, text is no longer an object but rather an event. The result is a deterritorialization, an incoherent politics, one which for Alexander Galloway "tends to dissolve existing institutional bonds," ${ }^{12}$ including the bonds of authorship. 


\section{An Ocean of Static}

The remainder of this article will focus on examples of page-based poetics inflected with the syntax and grammar of code languages emerging from my fourth book, An Ocean of Static (Carpenter 2018). I am not framing this book as a work in translation, but rather as a transitional object operating between human and machine languages, times, and spaces, a snapshot of on-going processes, an interruption, a lapsus, a slippage, a glitch.

Fig. 3

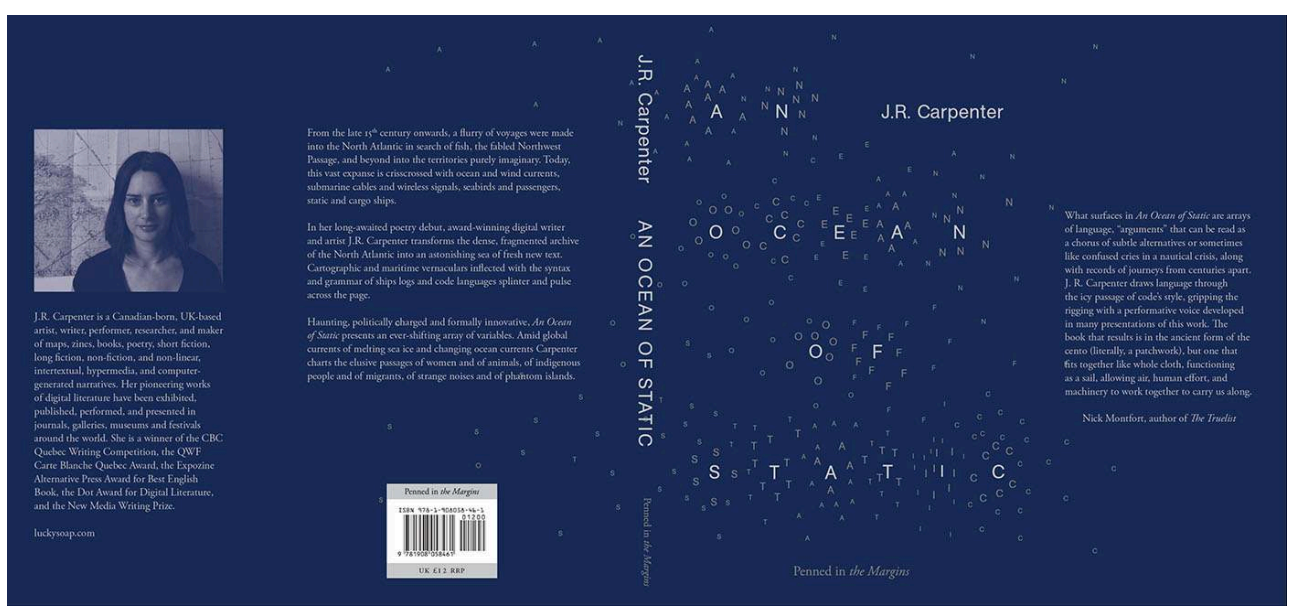

J. R. Carpenter, An Ocean of Static, London, Penned in the Margins, 2018.

The publisher, Penned in the Margins, promoted this book as my debut poetry collection. I don't really know what that means. This is a book born of an iterative compositional process wherein the act of writing is always an event, a movement in time, and that which is written is always on the cusp of becoming something else. Born of digital, variable, performative, embodied, and material processes, the texts in this book... I keep saying texts. My publisher would like me to say poems. The back cover blurb says:

Cartographic and maritime vernaculars inflected with the syntax and grammar of ships logs and code languages splinter and pulse across the page.

"Splinter and pulse" is nice. My publisher is a real poet. I was going to say "jolt and lurch."

Deleuze and Guattari famously quip: "There is no difference between what a book talks about and how it is made."13 This is book that talks about generations of transatlantic passages performed by currents, ships, packets, pens, and passengers. A diligent reader will have noticed by now that I tend to string sentences together like this - a statement followed by a long list of clauses. That's because I'm talking about a book made of variables, of strings, of arrays, of arguments:

This book is made of fragments - of ['other books', 'archives', 'ship \'s logs', 'source

codes', 'JavaScripts', 'scripts for live performance'].

A variable is a placeholder, and an argument is what fills it. Let's take for an example, a poem in An Ocean of Static called "Notes on the Voyage of Owl and Girl." ${ }^{14}$ The poem begins: 
An owl and a girl most ['adventurous', 'curious', 'studious'] ['set out', 'set sail', 'sailed away'] in a ['bottle-green', 'beetle-green', 'pea-green'] ['boat', 'sieve', 'skiff', 'vessel']; ${ }^{15}$. "Etheric Ocean" (119-134). This print poem is based on a digital poem called Etheric Ocean (2014), which was commissioned by Electronic Voice Phenomena, a Liverpool-based experimental literature and new media project exploring contemporary approaches to sound, voice, technology, and writing. The web-based iteration of Etheric Ocean presents an imprecise survey of sounds, signs, and distortions born of the difficulty of communicating through the medium of deep dense dark ocean. Like stations dotting a radio dial, murky diagrams, shifting definitions, appropriated texts, nautical associations, and word plays are strung along a long, horizontally scrolling browser window.

Hybrid, 7 | 2021 
In the opening screen a line of text reads: "this sea is nothing in sight but isles." An adjacent line translates the word "isles" into a visual pun: "I'll(s)" as in, multiple instances of "I will." Yet another line asks: "[What will you do?]" The answer is variable: the contraction "I'll" followed by a word or phrase randomly selected from an array of arguments compiled from the "w" section of the Collins English Dictionary. If this sea is nothing in sight but isles, these "w" words are watery waves washing worrying worshiping at the isles' shores. Whilst not literally a text in translation, this text performs a process akin to translation, endlessly proposing an excess of approximations, possibilities, equivalencies... however inadequate or absurd.

Fig. 4

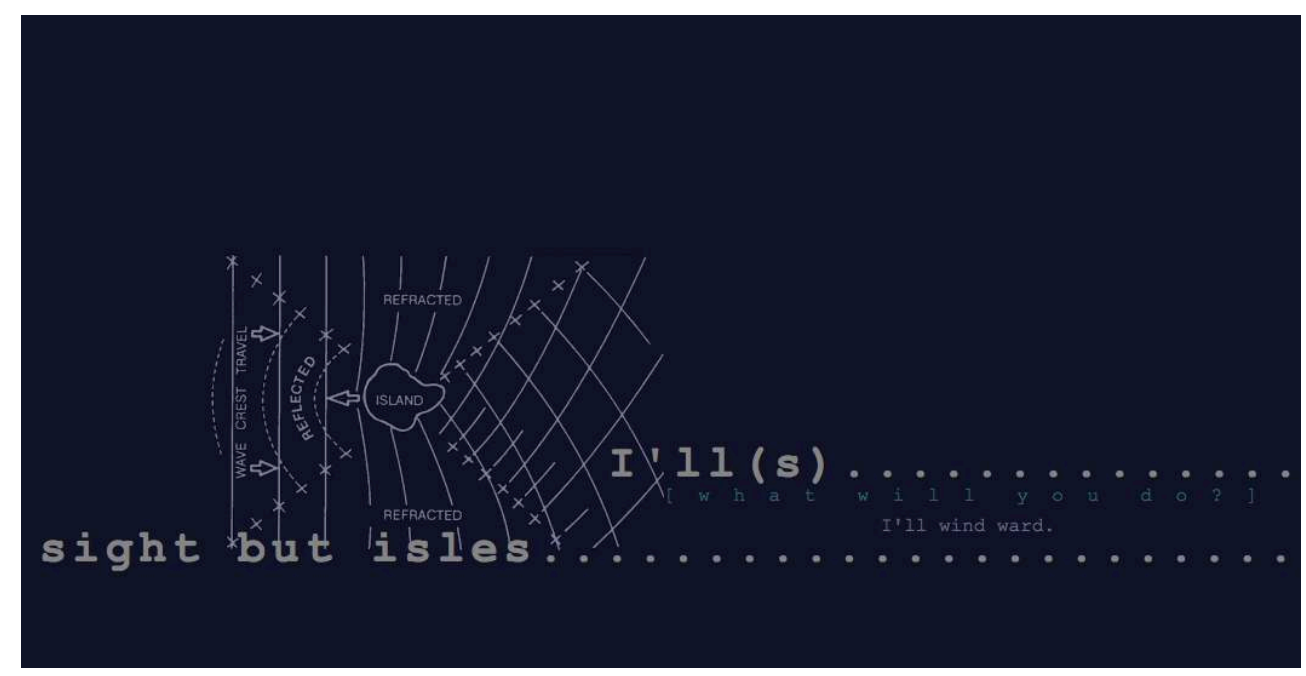

J. R. Carpenter, Etheric Ocean, 2014. [Online] http://luckysoap.com/ethericocean [accessed 13 April 2021].

In June 2014 I was invited by Penned in the Margins to present a performance based on the digital iteration of "Etheric Ocean" at a poetry performance event held in conjunction with the Museum of Water exhibition at Somerset House in London. I devised a print script for two voices, to be read along with a projection of the digital work being navigated from left to right. The print script soon became annotated with stage directions scribbled in pencil. As I would be reading long lists of arguments copied and pasted from JavaScript arrays, I found it useful to ['retain the JavaScript syntax in the print script', 'to guide me through otherwise grammatically impossible sentences'].

It is no coincidence that the word "script" appears in the name "JavaScript" JavaScript is a procedural language. Like a script for live performance, JavaScript must be written and read in a particular order in order to be performed by the web browser. When translating a text designed to be performed by a browser into a text designed to be performed by a human, what is carried or borne across? A human reader may require line breaks in places JavaScript would not. Indentation may come to indicate a second voice rather than a nested code item. Behind the screen, a square bracket means something quite different than it does on either the page or the stage. Publication standards for theatrical performance scripts vary from country to country. In some cases, square brackets may indicate stage directions. Similarly, JavaScript contains instructions akin to stage directions, not intended to be displayed on screen 
but rather to prompt an action. In other cases, square brackets in a stage play may indicate a localisation - a direction which invites the actor to substitute a word or phrase in the script with something relevant to the audience. Hello [local place name] becomes: Hello Paris. This usage is similar to JavaScript's use of square brackets to contain arrays.

In the digital iteration of "Etheric Ocean," the variable \{water\} can only call one water argument at a time. The print script uses the JavaScript as raw material to create a new text which presents some but not all of the water arguments. At the same time, the print script translates the random and ongoing selection process performed by the machine into a time frame intelligible to human readers:

I'll ['wade in', 'wait', 'wait a while'].

I'll ['walk in', 'walk away', 'walk on water'].

I'll ['water', 'down', 'fall', 'front', 'log', 'mark', 'meadow'].

I'll ['weaken', 'wean', 'wear', 'weather', 'warn', 'proof'].

I'll ['weather this storm'].

In 2014 I adapted this portion of the script for live performance for publication as a stand-alone poem called "this sea is nothing in sight but isles," in the online journal 3:AM Magazine (Carpenter 2014). The web page presents the text in exactly the same way as a print page would, with one notable exception. An <iframes embedded in the source code calls the exact same .js file as the web-based iteration of Etheric Ocean sitting on my web-server. This programmatic call on an outside source interrupts the human reading time/space with a reading/writing process happening in machine time.

In 2015 I translated the live performance iteration of Etheric Ocean work into an academic context for Sound Studies: Art, Experience, Politics, a three-day conference held at Cambridge University. Many elements of the performance script were carried across into the conference paper, which was also designed to be read whilst navigating the work from left to right. The conference paper situates both the digital text and the performance script in a broader historical and textual context, in large part through the apparatus of citation. In the conference paper we learn: "On his second voyage for the discovery of the Northwest Passage, attempted in 1586, Mister John Davis of Dartmouth, Devon, observed, "This land is nothing is sight but isles." In the digital iteration of Etheric Ocean, published 430 years later, "this land" becomes "this sea." I'm framing this change in wording as a translation of contexts, from a poetic performance to an academic one, from an Arctic ocean to an etheric one, from an ocean of ice to an ocean of static, an ocean of noise.

In 2016 I was invited to contribute to Hybrid. A Journal of Arts and Human Mediations, an online published by the University of Paris 8, the same journal in which this current article now appears. I submitted a version of the conference paper iteration of Etheric Ocean, adapted to be read by the eye rather than heard by the ear. This text was then translated from English into French. Although Hybrid is an online journal, I was sent a print copy of the translation by post, for me to proofread. In addition to translating the words from English to French, the translator had also translated the punctuation: from the straight quotation marks required for JavaScript to parse the source code, into guillemets, a punctuation mark particular to printed French.

$J^{\prime}[\ll$ interviens », « attends », « attends un moment »].

Je [« m'approche », « m'éloigne », « marche sur l'eau »].

Je [« eau », « en bas », « tombe », « devant », « journal », « marque », « prairie »].

Je [« faiblis », « sèvre », « use », « supporte », « préviens », « prouve »]. 
Je [« résiste à cette tempête »]

\section{block fraught with a textual excess spanning three full document pages. I quote a short} excerpt here to demonstrate the nature of the repetition in the translated text:

If you can't hear sound here, it's possible that your computer or browser doesn't support the file format. Or, If you can't hear sound here, it's possible that your computer or browser doesn't support the file format. Or, If you can't hear sound here, it's possible that your computer or browser doesn't support the file format. [...] Or, that you have your speakers turned off. that you have your speakers turned off.that you have your speakers turned off. that you have your speakers turned off.that you have your speakers turned off.that you have your speakers turned off. that you have your speakers turned off.that you have your speakers turned off.that you have your speakers turned off. that you have your speakers turned off.that you have your speakers turned off.that you have your speakers turned off. [...] Or, that you are a land mammal bending ear to hear sounds deep or, that you are a land mammal bending ear to hear sounds deep or, that you are a land mammal bending ear to hear sounds deep under water.under water.under water.under water. under water. under water.under water. under

Contrary to the underlying assumption implied by the common expression "lost in translation," that the translated text is somehow lesser, inferior, or lacking in precision or clarity, in this translation from one software to another, much was gained. This voluminous new text emerges through what Nathan Jones terms a "glitch incision [...] a lapse in a system that reveals another system." ${ }^{17}$ In this case, glitch incision revealed a profound misunderstanding between the Adobe Acrobat PDF reader and the email software about what constitutes a space between words, what is meant by a line break, and how best to fill these syntactical gaps in understanding. Jones goes on to say: "The human encounter with the glitch is so integral to its potency as a term, we might conclude that glitches only exist against human expectations." ${ }^{18}$ I was expecting the line I copied to be the line I pasted. I was so delighted by the email software's outpouring of new text that I immediately copied it from my email software, pasted it into a Word 
document, and started submitting it as a piece of conceptual writing to literary journals.

Rather than seeing this glitch as an inconsequential error or even a happy accident I see it as a perfectly logical outcome of an iterative and performative writing process. Is the text emerging from the from the glitch incision a translation? Perhaps it stands, rather, as a transcript of a momentary failure to communicate between mediums as disparate as land mammals, sound waves, computers, and oceans.

In August 2016, the British poet SJ Fowler and I used this glitch text as a script of sorts for an improvisational performance in two voices which we presented during The South West Poetry Tour. The text was published later that same year as "water.under" in a Canadian journal called The Goose $e^{19}$. In 2018 a shortened version of "water.under" was published within the body of the print iteration of "Etheric Ocean" which appears in An Ocean of Static.

I have provided a detailed account of the translation of but a few lines of but one of the texts in this book, between cultural, linguistic, and mediatic forms. Consider that most of the other texts, I mean poems, in An Ocean of Static have also undergone similar processes, moving across, beyond, and through print archives, digital networks, oceans, air, eyes, and ears. What has been carried over? What has endured? These are openended questions. Their answers are perhaps best sought in the book itself. An Ocean of Static is a book that bears the traces of its own making.

\section{BIBLIOGRAPHY}

Bolter, Jay David and Grusin, Richard, Remediation. Understanding New Media. Cambridge \& London: MIT Press, 1999.

Briggs, Kate, This Little Art, London, Fitzcarraldo, 2017.

Carpenter, J. R., “Entre Ville,” 2006. [Online] http://luckysoap.com/entreville [accessed 13 April 2021].

Carpenter, J. R., "Notes on the Voyage of Owl and Girl," 2013. [Online] http://luckysoap.com/ owlandgirl [accessed 29 December 2019].

Carpenter, J. R., "this sea is nothing in sight but isles," 3:AM MAGAZINE, 2014. [Online] https:// www.3ammagazine.com/3am/this-sea-is-nothing-in-sight-but-isles/ [accessed 29 December 2019].

Carpenter, J. R., "Etheric Ocean," 2014. [Online] http://luckysoap.com/ethericocean [accessed 29 December 2019].

Carpenter, J. R., “water.under,” The Goose, vol. 15, no. 1, 2016. [Online] https://scholars.wlu.ca/ thegoose/vol15/iss1/36/ [accessed 29 December 2019].

Carpenter, J. R., An Ocean of Static, London, Penned in the Margins, 2018. 
Carpenter, J. R. and Fowler, S. J., "water.under," South West Poetry Tour, Schumacher College, Devon, UK, 2016. [Online] https://www.youtube.com/watch?v=YJdBccXYmEo [accessed $1^{\text {st }}$ February 2020].

Deleuze, Gilles and Guattari, Félix, A Thousand Plateaus. Capitalism and Schizophrenia, Minneapolis, University of Minnesota Press, 2007.

Derrida, Jacques, Paper machine, translation Rachel Bowlby, Stanford, Stanford University Press, 2005.

Finnegan, Ruth, Why Do We Quote? The Culture and History of Quotation, Cambridge, Open Book Publishers, 2011.

Galloway, Alexander R., The Interface Effect, Cambridge, Polity, 2012.

Hall, John, Thirteen Ways of Talking about Performance Writing, Plytmouth, Plymouth College of Art Press, 2007.

Jones, Nathan, "Glitch poetics: The posthumanities of error," in Joseph Tabbi, (ed.), The Bloomsbury Handbook of Electronic Literature, London, Bloomsbury, 2017, p. 237-252.

Price, Adam O'Fallon, “Regarding the Em Dash,” The Millions, 2018. [Online] https:// themillions.com/2018/01/regarding-the-em-dash.html [accessed 27 June 2020].

Wark, McKenzie, The Beach Beneath the Street. The Everyday Life and Glorious Times of The Situationist International, London/New York, Verso, 2011.

\section{NOTES}

1. John Hall, Thirteen Ways of Talking about Performance Writing, Plymouth, Plymouth College of Art Press, 2007, p. 29.

2. Ruth Finnegan, Why Do We Quote? The Culture and History of Quotation, Cambridge, Open Book Publishers, 2011, p. 79.

3. Ruth Finnegan, Why Do We Quote? The Culture and History of Quotation, Cambridge, Open Book Publishers, 2011, p. 80.

4. Adam O'Fallon Price, "Regarding the Em Dash," The Millions, 2018. [Online] https:// themillions.com/2018/01/regarding-the-em-dash.html [accessed 27 June 2020].

5. Ruth Finnegan, Why Do We Quote? The Culture and History of Quotation, Cambridge, Open Book Publishers, 2011, p. 86.

6. Jay David Bolter and Richard Grusin, Remediation. Understanding New Media. Cambridge/London, MIT Press, 1999, p. 45.

7. Jacques Derrida, Paper machine, translation Rachel Bowlby, Stanford, Stanford University Press, 2005, p. 28.

8. Kate Briggs, This Little Art, London, Fitzcarraldo, 2017, p. 191.

9. McKenzie Wark, The Beach Beneath the Street. The Everyday Life and Glorious Times of The Situationist International, London/New York, Verso, 2011, p. 40.

10. Gilles Deleuze and Félix Guattari, A Thousand Plateaus. Capitalism and Schizophrenia, Minneapolis, University of Minnesota Press, 2007, p. 37.

11. Gilles Deleuze and Félix Guattari, A Thousand Plateaus. Capitalism and Schizophrenia, Minneapolis, University of Minnesota Press, 2007, p. 37.

12. Alexander R. Galloway, The Interface Effect, Cambridge, Polity, 2012, p. 47.

13. Gilles Deleuze and Félix Guattari, A Thousand Plateaus. Capitalism and Schizophrenia, Minneapolis, University of Minnesota Press, 2007, p. 4. 
14. J. R. Carpenter, An Ocean of Static, London, Penned in the Margins, 2018, p. 21 sqq.

15. J. R. Carpenter, An Ocean of Static, London, Penned in the Margins, 2018, p. 23.

16. J. R. Carpenter, "Notes on the Voyage of Owl and Girl," 2013. [Online] http://luckysoap.com/ owlandgirl [accessed 29 December 2019].

17. Nathan Jones, "Glitch poetics: The posthumanities of error," in Joseph Tabbi, (ed.), The Bloomsbury Handbook of Electronic Literature, London, Bloomsbury, 2017, p. 237.

18. Nathan Jones, "Glitch poetics: The posthumanities of error," in Joseph Tabbi, (ed.), The Bloomsbury Handbook of Electronic Literature, London, Bloomsbury, 2017, p. 239.

19. J. R. Carpenter, “water.under," The Goose, vol. 15, no. 1, 2016. [Online] https://scholars.wlu.ca/ thegoose/vol15/iss1/36/ [accessed 29 December 2019].

\section{ABSTRACTS}

This article traces the translation of texts between cultural and linguistic contexts, between academic and public-facing audiences, between print, digital, and performed forms. It is primarily concerned with questions of punctuation arising from the translation of poetic texts from digital into print contexts, with a particular attention to brackets and quotation marks. Building on a series of talks, its current iteration as an online publication this article continues an on-going exploration of the movement of language across, beyond, and through in-between spaces. The idea of "between" is considered here as a third time/space/state, a texture, an event, a palpable unfolding fraught with cacophony, liminality, atemporality and asynchronous exchanges. In keeping with its transient subject, this article alternates between lyrical and analytical modes.

\section{INDEX}

Keywords: digital literature, poetry, performance, publication, punctuation, translation

\section{AUTHOR}

\section{J. R. CARPENTER}

J. R. Carpenter is an artist, writer, and researcher working across performance, print, and digital media. Her work has been presented in museums, galleries, journals, and festivals around the world. Her web-based work The Gathering Cloud won the New Media Writing Prize 2016. Her print poetry collection An Ocean of Static was highly commended by the Forwards Prizes 2018. Her collection This is a Picture of Wind was named by The Guardian as one of the best poetry books of 2020. She is Writer-in-Residence at University of Alberta 2020-2021. Website: http:// luckysoap.com. 